\title{
Pleurotus ostreatus Mantarının Cips Üretiminde Kullanımı
}

\author{
Nurcan DOĞAN ${ }^{1 *}$, Cemhan DOĞAN ${ }^{1}$, Ibrahim HAYOĞLU ${ }^{2}$ \\ ${ }^{1}$ Bozok Üniversitesi, Boğazlıyan Meslek Yüksekokulu, Gıda İşleme Bölümü, YOZGAT \\ ${ }^{2}$ Harran Üniversitesi, Ziraat Fakültesi, Gıda Mühendisliği Bölümü, ŞANLIURFA \\ *Sorumlu yazar: nurcan.dogan@bozok.edu.tr
}

\begin{abstract}
Öz
Bu çalışmada atıştırmalık ürün sektöründe önde gelen cipsin istiridye mantarı tozu ile zenginleştirilmesi amaçlanmıştır. Üretimde kullanılacak hammaddelerin oranları ve pişirme parametreleri Yanıt Yüzey Yöntemi (YYY) esas alınarak denenmiştir. Üretilen cips örneklerinin, fizikokimyasal (kuru madde, kül, protein, su aktivitesi, yağ) ve duyusal analizleri sonuçlarına göre, mantar tozu oranı (MTO), kızartma süre ve sıcaklığı YYY ile optimize edilmiştir. Kızartılmış mantar cipsleri için optimum pişirme koşulları $180^{\circ} \mathrm{C}$, 155 sn ve \%40 MTO olarak belirlenmiştir. Bu norm doğrultusunda kuru madde, kül, protein, su aktivitesi, yağ ve duyusal analiz sonuçları sırası ile; $\% 99.10, \% 3.25, \% 15.10,0.10, \% 19.02$ ve 5.39 olarak saptanmıştır.
\end{abstract}

Anahtar Kelimeler: Istiridye mantarı, Pleurotus ostreatus, Mantar tozu, Cips, Kızartma

\section{Use of Pleurotus ostreatus Mushroom in Chips Production}

\begin{abstract}
In this study, chips, a leading product in the snacks sector, enriched with mushroom powder were investigated. Experimental design was constructed on the basis of the ratios of ingredients used in the manufacture and cooking parameters including mushroom powder ratio, cooking time and temperature were optimized according to the results obtained in physicochemical and sensory analyses in the trial production using Response Surface Method (RSM). Optimum cooking conditions for mushroom chips were determined as $180{ }^{\circ} \mathrm{C}, 155 \mathrm{sec}$ and $40 \%$ mushroom powder ratio. The dry matter, ash, protein, water activity, oil and the sensory evaluation results under optimal conditions were $99.10 \%, 3.25 \%$, $15.10 \%, 0.10,19.02 \%$ and 5.39 respectively.
\end{abstract}

Key Words: Oyster mushroom, Pleurotus ostreatus, Mushroom powder, Chips, Frying

\section{Giriş}

Toplumların yaşam tarzlarında olan değişimler, tüketime hazır atıştırmalık ürünlerin giderek artan oranda hayatımıza girmesine neden olmaktadır. Atıştırmalık gıdalar içerisinde cipsler önemli bir yer tutmaktadır. Ancak cipsler yağ ve nişasta oranı yüksek ve besleyici değeri düşük ürün olarak bilinirler (Mulsaney ve Hsieh, 1988). Geçtiğimiz yüzyılda, beslenme ve yeni gıda ürünü geliştirmede öncelikli olarak görünüm açısından çekiciliğe önem verilmiş, beslenme değeri ise dikkate alınmamıştır. Buna bağlı olarak obezite ve beslenmeye bağlı hastalıkların görülme sıklığı gün geçtikçe artmaktadır. Hastalıklarının kontrol altına alınması için günlük diyetin, fonksiyonel özelliği olan gıda bileşenleri ile zenginleştirilmesi önem taşımaktadır. Son yıllarda tüketicilerin sağlık üzerine yararlı etkileri olduğu bilinen fonksiyonel gıda 
ürünlerine eğilimleri, üreticileri bu kulvarda farklı gıda tasarımları yapmakta zorunlu kılmıştır. Ülkemizde kavak, kayın ve istiridye mantarı olarak bilinen Pleurotus ostreatus dünyada üretimi yapılan mantar türleri arasında ikinci sırada yer almaktadır (Öztürk ve Çopur, 2008). İstiridye mantarı yüksek besin değerinin yanı sıra tıbbi mantar (kolesterol düşürücü, antidiyabetik, antihipertansif) olarak da dikkat çekmektedir (Bobek ve ark., 1991; Schneider ve ark., 2011; Afrin ve ark., 2016). Mantar proteinleri bitkisel proteinlerden üstün olup, aminoasit kompozisyonundaki yakınlık dolayısıyla et, yumurta ve süt gibi hayvansal proteinlerle kıyaslanmaktadır. Mantar arjinin, aspartik asit, glutamik asit, treonin ve valin aminoasitleri açısından zengindir (Pesti, 2014). Mantar proteinleri etnik, dinsel-etik ve alerjik reaksiyonlar gibi nedenlerle protein ihtiyacını et ürünleri, balık, yumurta, süt gibi proteince zengin gıdalardan sağlayamayan bireyler için uygundur. Mantarın bileşimi ile ilgili dikkat çeken önemli hususlardan biri enerji içeriğinin düşük olması ve tokluk hissi vermesidir. Yapılan çalışmalarda et ve mantar diyetleri ile beslenen bireylerde genel tokluk hissi, yenilebilirlik ve lezzet gibi parametreler açısından fark görülmez iken, mantar diyeti ile beslenen deneklerin et diyetine kıyasla enerji alımı, kilo kaybı, bel çevresi yağ oranı, toplam vücut yağı, vücutkitle indeksi, sistolik ve diastolik kan basıncı parametrelerinde önemli düzelmeler olduğu belirlenmiştir (Cheskin ve ark., 2008; Poddar ve ark., 2013). Mantarların taze ve işlenmiş ürünleri dünya çapında yoğun talep görmektedir. Beslenme özelliği açısından iyi derecede protein kaynağı olması yanında fizyolojik fonksiyonları düzenleyen organik bileşikler içermektedir (Sarangi ve ark., 2006). Mantar veya mantardan izole edilmiş biyoaktif bileşenlerin düzenli şekilde tüketilmesinin sağlık açısından yararlı olacağı belirtilmektedir. Bu yüzden mantarlara fonksiyonel gıda gözüyle bakılmaktadır (Erbay ve Küçüköner, 2008). İstiridye mantarının üretim, beslenme özellikleri ve biyoaktif özelliklerinin belirlenmesi (Poppe, 2000; Ragunathan ve Swaminathan, 2003) alanında çok sayıda çalışma yapılmış olup gıda işleme teknolojisi alanında yeterli çalışmaya rastlanılmamıştır.

Bu çalışmanın amacı, toz halindeki istiridye mantarını, cips hamuru formülasyonunda kullanmak ve kızartılmış cips üretmektir. Bunun yanı sıra cips tipi atıştırmalık ürünlerin çocuk ve gençlerin yoğun ölçüde tükettiği bir gıda ürünü olduğu düşünüldüğünde, bu ürüne mantar tozu ilavesi ile mevcut cipslere nazaran daha doğal ve besleyici değeri yüksek bir ürün ortaya çıkarılabileceği ve atıştırmalık ürünlerde önde gelen patates, mısır ve tahıl cipslerine alternatif olacağı düşünülmektedir.

\section{Materyal ve Metot}

\section{Materyal}

Cips hamuru formülasyonunda kullanılan İstiridye mantarı tozu (Doğan, 2015; Doğan, 2016)'de belirtildiği üzere üretilmiştir. Buğday unu ve kızartma yağı yerel firmalardan temin edilmiş olup su olarak mantarın kendi haşlama suyu kullanılmıştır.

\section{Metot}

Cips üretimi

Cips hamurunun yapımında kullanılan mantar tozu oranı (MTO) ve pişirme parametreleri olan, kızartma süre ve sıcaklığı, Design Expert 7. istatiksel paket programının Yanıt Yüzey Yöntemi altında ve merkezi kompozit tasarımı modeli esas alınarak belirlenmiştir. Kullanılan su miktarı literatür çalışmaları ve yapılan ön denemeler sonucunda mantar tozu için 1:1 oranında, 
buğday unu için ise 1:0.6 olarak belirlenmiştir (Yüksel, 2014;Doğan, 2016). Uygun formülasyonlarda hazırlanan hammaddeler hamur yoğurma makinasında (Kitchen Aid, Professional $600 \mathrm{MI}$, USA) yoğrulduktan sonra $45 \mathrm{dk}$. dinlendirilmiştir. Dinlendirilen hamur, hamur açma makinesinde (Rondo, Doge SS0615, İsviçre) kademeli olarak $16-8$ $-4-2$ ve en son $1 \mathrm{~mm}$ kalınlıkta açılımıs ve kenar uzunlukları 3-6 cm olan kalıpla şekil verilip yă̆ banyosu (Mikrotest, Türkiye) kullanılarak kızartılmıştır (Şekil 1.).

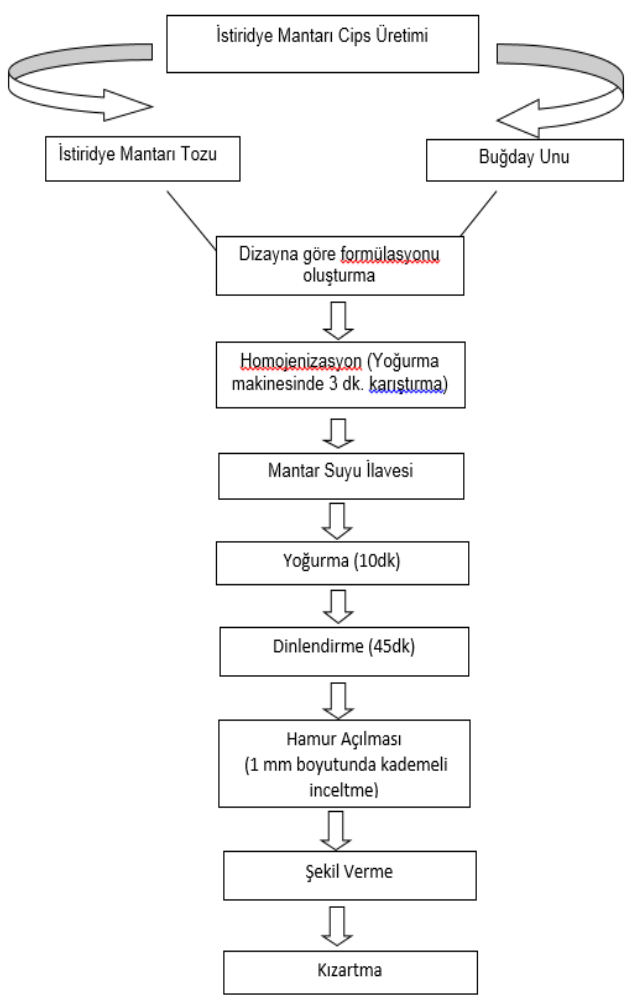

Şekil 1. Kızartılmış mantar cipsi üretim akış şeması

Figure 1. Process diagram for fried mushroom chips

Cips örneklerinde yapılan analizler:

Kuru madde analizi

Sabit tartıma getirilen kaplara cips örnekleri tartılmış ve $105 \pm 3$ oC'ye ayarlı etüvde (Daihan, Korea) sabit tartıma (>3 saat) gelinceye kadar kurutulmuştur (AOAC, 2000).

\section{Yağ analizi}

Kızartılmış cips örneklerinin yağ içeriği, solvent ekstraksiyonu yöntemine göre saptanmıştır (Doğan, 2016).

\section{Kül analizi}

Ön yakma işlemine tabi tutulan örneklere kül fırınında yakma işlemi uygulanmıştır. Soğutulan örnekler sabit ağırlığa gelince tartım alınarak \% kül miktarı hesaplanmıştır (AOAC, 2000).

\section{Protein miktarı tayini}

Örneklerin protein analizi Kjeldahl yöntemine göre yapılmıştır (AOCS, 1999).

\section{Su aktivitesi tayini}

Örneklerin su aktivitesi değerleri otomatik su aktivitesi tayin cihazı (Aqualab Series 3T, ABD) kullanılarak belirlenmiştir (AOAC, 2000).

\section{Duyusal analiz}

Cips örneklerinin duyusal analizleri 10 kişilik bir panel grubu tarafından gerçekleştirilmiştir. Panelistlerden örnekleri renk, tat ve gevreklik özellikleri açısından 7 ölçekli hedonik tip skala ile değerlendirmeleri istenmiştir. Daha sonra 3 özelliğe ait puanın aritmetik ortalaması alınarak genel beğeni puanı hesaplanmıştır.

Yanıt yüzey yöntemine göre deney tasarımlarının oluşturulması

Kızartılmış cips örnekleri için; MTO, kızartma süre ve sıcaklığı faktör olarak seçilerek, 3 faktör 5 seviye merkezi kompozit tasarımı deneme tasarımı oluşturulmuştur (Çizelge 1.). Denemeler sistematik hataları minimize edebilmek için gelişi güzel sıralama ile gerçekleştirilmiştir. 
Çizelge 1. Kızartılmış istiridye mantarı cips için 3 faktör-5 seviye merkezi kompozit tasarımı Table 1.3 factor -5 level central composite design for fried mushroom chips

\begin{tabular}{|c|c|c|c|c|}
\hline $\begin{array}{c}\text { Deneme no } \\
\text { Test no }\end{array}$ & $\begin{array}{l}\text { Deneme } \\
\text { sırası } \\
\text { Test order }\end{array}$ & $\begin{array}{l}\text { Kızartma } \\
\text { sıcaklığı }\left({ }^{\circ} \mathrm{C}\right) \\
\text { Frying } \\
\text { temperature }\left({ }^{\circ} \mathrm{C}\right)\end{array}$ & $\begin{array}{l}\text { Kızartma süresi } \\
\text { (Sn) } \\
\text { Frying time(sec) }\end{array}$ & $\begin{array}{l}\text { Mantar oranı (\%) } \\
\text { Mushroom } \\
\text { ratio(\%) }\end{array}$ \\
\hline 1 & 18 & 150 & 50 & 20 \\
\hline 2 & 15 & 180 & 50 & 20 \\
\hline 3 & 16 & 150 & 180 & 20 \\
\hline 4 & 19 & 180 & 180 & 20 \\
\hline 5 & 20 & 150 & 50 & 40 \\
\hline 6 & 12 & 180 & 50 & 40 \\
\hline 7 & 3 & 150 & 180 & 40 \\
\hline 8 & 11 & 180 & 180 & 40 \\
\hline 9 & 8 & 139.77 & 115 & 30 \\
\hline 10 & 13 & 190.23 & 115 & 30 \\
\hline 11 & 6 & 165 & 5.68 & 30 \\
\hline 12 & 17 & 165 & 224.32 & 30 \\
\hline 13 & 7 & 165 & 115 & 13.18 \\
\hline 14 & 9 & 165 & 115 & 46.82 \\
\hline 15 & 10 & 165 & 115 & 30 \\
\hline 16 & 2 & 165 & 115 & 30 \\
\hline 17 & 1 & 165 & 115 & 30 \\
\hline 18 & 5 & 165 & 115 & 30 \\
\hline 19 & 4 & 165 & 115 & 30 \\
\hline 20 & 14 & 165 & 115 & 30 \\
\hline
\end{tabular}

Not: 9. ve 10. deneme noktalarındaki kızartma sıcaklıkları ve 11. ve 12. deneme noktalarındaki kızartma süreleri teknik olarak uygulanamayacağından, 9. deneme noktasındaki kızartma sıcaklığı olan 139.77 C, 140 C olarak; 10. deneme noktasındaki 190.23 oC'de 190 C olarak, 11. deneme noktasındaki 5.68 sn olan kızartma süresi 6 sn, 12. deneme noktasındaki 224.32 sn olan kızartma süresi 224 sn olarak uygulanmıştır.

Istatistik analiz ve optimizasyon

Ürünlerin optimizasyonu Design Expert yazılımının numerik optimizasyon yöntemine göre yapılmıştır (Myers ve Montgomery, 2002). Deneme tasarımlarından elde edilen verilerin regresyon ve varyans analizleri ile optimizasyon işlemi Design Expert (Versiyon:7.0, StatEase, ABD) paket programının merkezi kompozit tasarımı modeli esas alınarak gerçekleştirilmiştir. Örnek ortalama karşılaştırmaları SPSS 22.0 istatistik paket programı kullanılarak Duncan çoklu karşılaştırma testi ile belirlenmiştir.

\section{Araştırma Bulguları ve Tartışma}

\section{Fizikokimyasal Analizler}

Kızartılmış istiridye mantarı tozu katkılı cips üretiminde paket programın verdiği deneme noktalarına göre üretimler yapılmış olup örneklere ait bazı fizikokimyasal özellikler ve genel beğeni Çizelge 2 . de verilmiştir. Uygulanan MTO, kızartma sıcaklığı ve süresinin yanıt yüzey yöntemi ile yapılan deneme desenine göre elde edilen cips örneklerinin kuru madde, kül, protein, $a_{w}$ ve yağ miktarı üzerine etkisini ortaya koyan polinom denklemler verilmiştir (Çizelge 3.). 
Çizelge 2. Kızartılmış istiridye mantarı tozu katkılı cips örneklerine ait bazı fizikokimyasal ve duyusal analiz sonuçları

Table 2.Some physicochemical and sensory analysis results of fried chips with oyster mushroom powder ${ }^{\phi}$

\begin{tabular}{|c|c|c|c|c|c|c|c|c|c|}
\hline $\begin{array}{c}\text { Denem } \\
\text { e no } \\
\text { Test } \\
\text { no }\end{array}$ & \begin{tabular}{|c|} 
Kızartma \\
sıcaklığı \\
Frying \\
temperature \\
$\left({ }^{\circ} \mathrm{C}\right)$ \\
\end{tabular} & $\begin{array}{l}\text { Kızartma } \\
\text { süresi } \\
\text { frying } \\
\text { time } \\
\text { (s) }\end{array}$ & $\begin{array}{c}\text { Mantar } \\
\text { Oranı } \\
\text { Mushroom } \\
\text { ratio } \\
(\%)\end{array}$ & $\begin{array}{c}\text { Kuru } \\
\text { madde } \\
\text { Dry } \\
\text { matter } \\
(\%) \\
\end{array}$ & $\begin{array}{l}\text { Kül* } \\
\text { Ash } \\
(\%)\end{array}$ & $\begin{array}{l}\text { Protein* } \\
\text { (\%) }\end{array}$ & $a_{w}$ & $\begin{array}{l}\text { Yağ* } \\
\text { Fat } \\
(\%)\end{array}$ & $\begin{array}{c}\text { Genel } \\
\text { beğeni } \\
\text { Overal } \\
\text { appreciation }\end{array}$ \\
\hline 1 & 150 & 50 & 20 & $\begin{array}{c}97.14 \\
\pm 1.48^{\mathrm{b}}\end{array}$ & $\begin{array}{c}1.75 \\
\pm 0.28^{\mathrm{gh}}\end{array}$ & $\begin{array}{c}11.85 \\
\pm 1.22^{\mathrm{gh}}\end{array}$ & $\begin{array}{c}0.19 \\
\pm 0,03^{b}\end{array}$ & $\begin{array}{c}21.18 \\
\pm 0.28^{\mathrm{bcd}}\end{array}$ & $\begin{array}{c}5.35 \\
\pm 0.14^{\mathrm{bcd}}\end{array}$ \\
\hline 2 & 180 & 50 & 20 & $\begin{array}{c}98.10 \\
\pm 1.16^{\mathrm{ab}}\end{array}$ & $\begin{array}{c}1.96 \\
\pm 0.11^{\mathrm{efh}}\end{array}$ & $\begin{array}{c}12.92 \\
\pm 0.72^{\text {efgh }}\end{array}$ & $\begin{array}{c}0.14 \\
\pm 0.16^{\mathrm{b}}\end{array}$ & $\begin{array}{c}20.15 \\
\pm 0.51^{\text {cdef }}\end{array}$ & $\begin{array}{c}6.10 \\
\pm 0.30^{\mathrm{ab}}\end{array}$ \\
\hline 3 & 150 & 180 & 20 & $\begin{array}{c}97.60 \\
\pm 0.89^{\mathrm{ab}}\end{array}$ & $\begin{array}{c}1.89 \\
\pm 0.28^{\mathrm{gh}}\end{array}$ & $\begin{array}{c}12.65 \\
\pm 0.47^{\mathrm{efgh}}\end{array}$ & $\begin{array}{c}0.17 \\
\pm 0.00^{b}\end{array}$ & $\begin{array}{r}23.43 \\
\pm 0.26^{\mathrm{a}}\end{array}$ & $\begin{array}{c}6.10 \\
\pm 0.91^{\mathrm{ab}}\end{array}$ \\
\hline 4 & 180 & 180 & 20 & $\begin{array}{c}98.50 \\
\pm 1.94^{\mathrm{ab}}\end{array}$ & $\begin{array}{c}2.15 \\
\pm 0.06^{\mathrm{efg}}\end{array}$ & $\begin{array}{c}13.29 \\
\pm 0.30^{\text {defg }}\end{array}$ & $\begin{array}{c}0.12 \\
\pm 0.01^{\mathrm{b}}\end{array}$ & $\begin{array}{c}21.10 \\
\pm 1.71^{\mathrm{bcd}}\end{array}$ & $\begin{array}{c}5.89 \\
\pm 0.13^{\mathrm{abc}}\end{array}$ \\
\hline 5 & 150 & 50 & 40 & $\begin{array}{c}98.10 \\
\pm 1.51^{\mathrm{ab}}\end{array}$ & $\begin{array}{c}3.08 \\
\pm 0.04^{\mathrm{abc}}\end{array}$ & $\begin{array}{c}14.42 \\
\pm 0.18^{\text {bcde }}\end{array}$ & $\begin{array}{c}0.11 \\
\pm 0.01^{\mathrm{b}}\end{array}$ & $\begin{array}{c}19.80 \\
\pm 1.15^{\text {defg }}\end{array}$ & $\begin{array}{c}4.00 \\
\pm 0.21^{\text {ef }}\end{array}$ \\
\hline 6 & 180 & 50 & 40 & $\begin{array}{c}98.71 \\
\pm 0.21^{\mathrm{ab}}\end{array}$ & $\begin{array}{c}3.25 \\
\pm 0.54^{\mathrm{ab}}\end{array}$ & $\begin{array}{c}15.91 \\
\pm 0.20^{\mathrm{ab}}\end{array}$ & $\begin{array}{c}0.10 \\
\pm 0.01^{\mathrm{b}}\end{array}$ & $\begin{array}{c}17.19 \\
\pm 0.37^{\text {hij }}\end{array}$ & $\begin{array}{c}4.15 \\
\pm 0.14^{\text {ef }}\end{array}$ \\
\hline 7 & 150 & 180 & 40 & $\begin{array}{c}99.50 \\
\pm 0.42^{\mathrm{ab}}\end{array}$ & $\begin{array}{c}3.00 \\
\pm 0.16^{\mathrm{bcd}}\end{array}$ & $\begin{array}{c}15.99 \\
\pm 0.74^{\mathrm{ab}}\end{array}$ & $\begin{array}{c}0.12 \\
\pm 0.00^{b}\end{array}$ & $\begin{array}{c}21.02 \\
\pm 1.34^{\mathrm{bcd}}\end{array}$ & $\begin{array}{c}4.20 \\
\pm 0.95^{\text {ef }}\end{array}$ \\
\hline 8 & 180 & 180 & 40 & $\begin{array}{r}99.86 \\
\pm 0.04^{\mathrm{a}}\end{array}$ & $\begin{array}{c}3.32 \\
\pm 0.06^{\mathrm{ab}}\end{array}$ & $\begin{array}{l}16.58 \\
\pm 0.69^{\mathrm{a}}\end{array}$ & $\begin{array}{c}0.10 \\
\pm 0.01^{\mathrm{b}}\end{array}$ & $\begin{array}{c}19.26 \\
\pm 0.18^{\text {defgh }}\end{array}$ & $\begin{array}{c}4.75 \\
\pm 0.62^{\text {de }}\end{array}$ \\
\hline 9 & 139.77 & 115 & 30 & $\begin{array}{c}97.35 \\
\pm 1.70^{\mathrm{ab}}\end{array}$ & $\begin{array}{c}2.40 \\
\pm 0.07^{\text {ef }}\end{array}$ & $\begin{array}{c}13.50 \\
\pm 1.44^{\text {cdefg }}\end{array}$ & $\begin{array}{c}0.18 \\
\pm 0.06^{b}\end{array}$ & $\begin{array}{c}20.48 \\
\pm 0.00^{\text {bcde }}\end{array}$ & $\begin{array}{c}3.55 \\
\pm 0.07^{f}\end{array}$ \\
\hline 10 & 190.23 & 115 & 30 & $\begin{array}{l}99.48 \pm \\
0.10^{\mathrm{ab}}\end{array}$ & $\begin{array}{c}2.56 \\
\pm 0.13^{\text {de }}\end{array}$ & $\begin{array}{c}14.90 \\
\pm 1.27^{\text {abcd }}\end{array}$ & $\begin{array}{c}0.11 \\
\pm 0.01^{\mathrm{b}}\end{array}$ & $\begin{array}{c}17.82 \\
\pm 0.34^{\text {ghi }}\end{array}$ & $\begin{array}{c}5.45 \\
\pm 0.06^{\mathrm{bcd}}\end{array}$ \\
\hline 11 & 165 & 5.68 & 30 & $\begin{array}{c}93.33 \\
\pm 0.17^{\mathrm{ab}}\end{array}$ & $\begin{array}{c}1.90 \\
\pm 0.11^{\mathrm{gh}}\end{array}$ & $\begin{array}{c}12.50 \\
\pm 0.72^{\mathrm{fgh}}\end{array}$ & $\begin{array}{c}0.51 \\
\pm 0.37^{\mathrm{a}}\end{array}$ & $\begin{array}{l}15.50 \\
\pm 1.00^{j}\end{array}$ & $\begin{array}{c}2.50 \\
\pm 0.27^{g}\end{array}$ \\
\hline 12 & 165 & 224.32 & 30 & $\begin{array}{c}98.95 \\
\pm 0.76^{\mathrm{ab}}\end{array}$ & $\begin{array}{c}2.63 \\
\pm 0.11^{\text {cde }}\end{array}$ & $\begin{array}{c}15.10 \\
\pm 0.49^{\mathrm{abc}}\end{array}$ & $\begin{array}{c}0.12 \\
\pm 0.02^{b}\end{array}$ & $\begin{array}{c}22.11 \\
\pm 0.47^{\mathrm{abc}}\end{array}$ & $\begin{array}{c}5.85 \\
\pm 0.01^{\mathrm{abc}}\end{array}$ \\
\hline 13 & 165 & 115 & 13.18 & $\begin{array}{c}97.50 \\
\pm 0.71^{\mathrm{ab}}\end{array}$ & $\begin{array}{c}1.51 \\
\pm 0.08^{h}\end{array}$ & $\begin{array}{l}11.45 \\
\pm 0.48^{h}\end{array}$ & $\begin{array}{c}0.20 \\
\pm 0.02^{b}\end{array}$ & $\begin{array}{c}22.50 \\
\pm 0.68^{\mathrm{ab}}\end{array}$ & $\begin{array}{c}6.31 \\
\pm 0.18^{\mathrm{a}}\end{array}$ \\
\hline 14 & 165 & 115 & 46.82 & $\begin{array}{c}99.86 \\
\pm 0.16^{\mathrm{a}}\end{array}$ & $\begin{array}{c}3.49 \\
\pm 0.21^{\mathrm{a}}\end{array}$ & $\begin{array}{c}15.25 \\
\pm 0.28^{\mathrm{abc}}\end{array}$ & $\begin{array}{c}0.09 \\
\pm 0.03^{b}\end{array}$ & $\begin{array}{r}16.30 \\
\pm 1.15^{\mathrm{ij}}\end{array}$ & $\begin{array}{c}3.50 \\
\pm 0.23^{f}\end{array}$ \\
\hline 15 & 165 & 115 & 30 & $\begin{array}{c}98.25 \\
\pm 0.55^{\mathrm{ab}}\end{array}$ & $\begin{array}{c}2.50 \\
\pm 0.21^{\mathrm{e}}\end{array}$ & $\begin{array}{c}14.10 \\
\pm 0.79^{\text {cdef }}\end{array}$ & $\begin{array}{c}0.14 \\
\pm 0.03^{b}\end{array}$ & $\begin{array}{c}17.83 \\
\pm 0.68^{\text {ghi }}\end{array}$ & $\begin{array}{c}5.13 \\
\pm 0.13^{\text {cd }}\end{array}$ \\
\hline 16 & 165 & 115 & 30 & $\begin{array}{c}98.19 \\
\pm 0.82^{\mathrm{ab}}\end{array}$ & $\begin{array}{r}2.45 \\
\pm 0.41^{\mathrm{e}}\end{array}$ & $\begin{array}{c}13.90 \\
\pm 1.02^{\text {cdef }}\end{array}$ & $\begin{array}{c}0.14 \\
\pm 0.02^{\mathrm{b}}\end{array}$ & $\begin{array}{c}19.70 \\
\pm 1.60^{\operatorname{defg}}\end{array}$ & $\begin{array}{c}5.17 \\
\pm 0.25^{\mathrm{cd}}\end{array}$ \\
\hline 17 & 165 & 115 & 30 & $\begin{array}{c}98.51 \\
\pm 1.36^{\mathrm{ab}}\end{array}$ & $\begin{array}{c}2.54 \\
\pm 0.01 \mathrm{~d}^{\mathrm{e}}\end{array}$ & $\begin{array}{c}13.65 \\
\pm 0.58^{\text {cdefg }}\end{array}$ & $\begin{array}{c}0.14 \\
\pm 0.02^{\mathrm{b}}\end{array}$ & $\begin{array}{c}17.83 \\
\pm 1.34^{\text {ghi }}\end{array}$ & $\begin{array}{c}5.30 \\
\pm 0.18^{\mathrm{bcd}}\end{array}$ \\
\hline 18 & 165 & 115 & 30 & $\begin{array}{c}98.61 \\
\pm 1.23^{\mathrm{ab}}\end{array}$ & $\begin{array}{c}2.39 \\
\pm 0.03^{\text {ef }}\end{array}$ & $\begin{array}{c}13.10 \\
\pm 0.58^{\text {efgh }}\end{array}$ & $\begin{array}{c}0.14 \\
\pm 0.02^{\mathrm{b}}\end{array}$ & $\begin{array}{c}18.20 \\
\pm 0.86^{\text {fghi }}\end{array}$ & $\begin{array}{c}5.05 \\
\pm 0.10^{\mathrm{cd}}\end{array}$ \\
\hline 19 & 165 & 115 & 30 & $\begin{array}{c}98.38 \\
\pm 0.89^{\mathrm{ab}}\end{array}$ & $\begin{array}{c}2.55 \\
\pm 0.06^{\text {de }}\end{array}$ & $\begin{array}{c}12.99 \\
\pm 0.82^{\text {efgh }}\end{array}$ & $\begin{array}{c}0.14 \\
\pm 0.00^{\mathrm{b}}\end{array}$ & $\begin{array}{c}19.48 \\
\pm 0.92^{\operatorname{defg}}\end{array}$ & $\begin{array}{c}5.35 \\
\pm 0.08^{\mathrm{bcd}}\end{array}$ \\
\hline 20 & 165 & 115 & 30 & $\begin{array}{c}98.41 \\
\pm 1.24^{\mathrm{ab}}\end{array}$ & $\begin{array}{c}2.40 \\
\pm 0.23^{\text {ef }}\end{array}$ & $\begin{array}{c}12.95 \\
\pm 0.48^{\text {efgh }}\end{array}$ & $\begin{array}{c}0.13 \\
\pm 0.03^{b}\end{array}$ & $\begin{array}{c}18.30 \\
\pm 0.55^{\text {efghi }}\end{array}$ & $\begin{array}{c}5.48 \\
\pm 0.10^{\mathrm{abcd}}\end{array}$ \\
\hline
\end{tabular}

Her bir sütundaki farklı harfler örneklerin istatistiksel olarak farklı olduğunu göstermektedir $(p<0.05)$

* \% Kuru madde üzerinden hesaplanmıştır. 
Çizelge 3. Kızartılmış istiridye mantarı cipsinin bazı bileşim özelliklerinin matematiksel modellemesi

Table 3. Mathematical modeling of some compositional properties of fried oyster mushroom chips

\begin{tabular}{|c|c|c|}
\hline $\begin{array}{l}\text { Bileşim Özellikleri } \\
\text { Composition Properties }\end{array}$ & Model & $R^{2}$ \\
\hline $\begin{array}{l}\text { Kuru madde (\%) } \\
\text { Dry matter (\%) }\end{array}$ & $\begin{array}{l}\text { 90.19+0.06 } \mathrm{X}_{1}-9.75 \mathrm{E}-003 \mathrm{X}_{2}-0.01 \mathrm{X}_{3}+8.85 \mathrm{E}-005 \mathrm{X}_{1} \mathrm{X}_{2}+1.33 \mathrm{E}-004 \mathrm{X}_{2} \mathrm{X}_{3^{-}} \\
1.077 \mathrm{E}-004 \mathrm{X}_{1}^{2}-1.58 \mathrm{E}-005 \mathrm{X}_{2}^{2}+6.94 \mathrm{E}-004 \mathrm{X}_{3}^{2}\end{array}$ & 0.95 \\
\hline $\begin{array}{l}\text { Kül } \\
\text { Ash }\end{array}$ & $\begin{array}{l}\text { 3.92-0.04X }{ }_{1}+1.86 E-003 X_{2}+0.041 X_{3}+2.56 E-005 X_{1} X_{2}+1.67 E-005 X_{1} X_{3}- \\
6.54 E-005 X_{2} X_{3}+1.43 E-004 X_{1}^{2}-1.04 E-005 X_{2}^{2}+3.92 E-004 X_{3}^{2}\end{array}$ & 0.96 \\
\hline Protein (\%) & 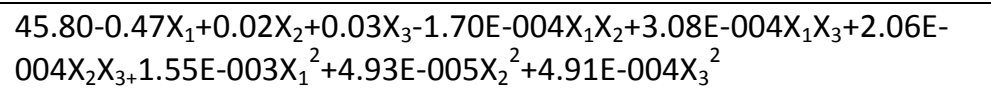 & 0.93 \\
\hline$a_{w}$ & $\begin{array}{l}0.85-4.65 \mathrm{E}-003 \mathrm{X}_{1}+3.20 \mathrm{E}-004 \mathrm{X}_{2}-0.01 \mathrm{X}_{3}-1.28 \mathrm{E}-006 \mathrm{X}_{1} \mathrm{X}_{2}+5.83 \mathrm{E}- \\
005 \mathrm{X}_{1} \mathrm{X}_{3}+8.46 \mathrm{E}-006 \mathrm{X}_{2} \mathrm{X}_{3}+5.58 \mathrm{E}-006 \mathrm{X}_{1}^{2}-1.75 \mathrm{E}-006 \mathrm{X}_{2}^{2}-3.35 \mathrm{E}-006 \mathrm{X}_{3}^{2}\end{array}$ & 0.96 \\
\hline $\begin{array}{l}\text { Yağ } \\
\text { Fat (\%) }\end{array}$ & $\begin{array}{l}\text { 68.61-0.46X } \mathrm{X}_{1}-0.03 \mathrm{X}_{2}-0.23 \mathrm{X}_{3}-5.77 \mathrm{E}-005 \mathrm{X}_{1} \mathrm{X}_{2}-8.42 \mathrm{E}-004 \mathrm{X}_{1} \mathrm{X}_{3}+1.73 \mathrm{E}-005 \\
\mathrm{X}_{2} \mathrm{X}_{3}+1.32 \mathrm{E}-003 \mathrm{X}_{1}^{2}+2.37 \mathrm{E}-004 \mathrm{X}_{2}^{2}+3.85 \mathrm{E}-003 \mathrm{X}_{3}^{2}\end{array}$ & 0.90 \\
\hline
\end{tabular}

Kızartılmış cips örneklerinde kuru madde, kül ve protein miktarı sıcaklık, süre ve MTO'ya bağlı olarak artmıştır $(p<0.05)$ (Şekil 2.). Cips gibi çerez gıdalar yüksek sıcaklıklara maruz kaldığında buharlaşmaya bağlı olarak nem içeriğinin düşük olması çalışma sonucunu desteklemektedir (Cankurtaran, 2008; Yüksel, 2014). Kızartılmış cips örneklerinin kül miktarının sade buğday cipsinden (Yüksel, 2014). yüksek çıkmasının ve MTO'ya bağlı olarak artmasının nedeni mantarın mineral madde açısından son derece zengin olmasından kaynaklandığı düşünülmektedir. Mantar cipsinde de en fazla proteinin \%40 MTO katkılı cipslerde olması, protein değeri yüksek olan besin bileşenlerinin formülasyona ilavesinin son üründeki protein değerini arttıracağını göstermesi (Iwe, 2000; Martinez-Flores ve ark., 2005), açısından eklenilen bir durumdur.

Kızartılmış cips örneklerine ait aw değeri sıcaklık ve MTO’nun artışına bağıı olarak azalırken $\quad(p<0.05), \quad$ kızartma süresi istatistiksel olarak önemsiz bulunmuştur ( $p>0.05$ ) (Şekil 3.). Örneklerin su aktivitesi değerlerinin düşük çıkması derin yağda kızartma işlemi esnasında örneklerin nem içeriklerin azalması ile açıklanabilir (Konopacka ve ark., 2002). Çalışamadan elde edilen sonuçlara göre kızartılmış cips düşük nemli gıdalar sınıfına girmektedir (Aguilera ve Arias, 1992).

Kızartılmış mantar cipslerinde yağ miktarı, kızartma sıcaklığı ve MTO artışına bağı olarak azalırken, kızartma süresi arttıkça artmıştır $(p<0.05)$ (Şekil 4.). Gıdalar kızgın yağa daldırıldıklarında üründeki su buharlaşmakta ve oluşan porlardan yağ içeri emilmektedir. Kızartma sıcaklığına bağlı olarak kızartmanın ilk 20-30 saniyesinden sonra gıdadaki nem kaybının azalmasına paralel olarak yağ emilimi de azalmaktadır. $\mathrm{Bu}$ mekanizmaya göre kızartma sıcaklığı yükseldikçe yağ emilim miktarı düşmektedir (Mellema, 2003). 

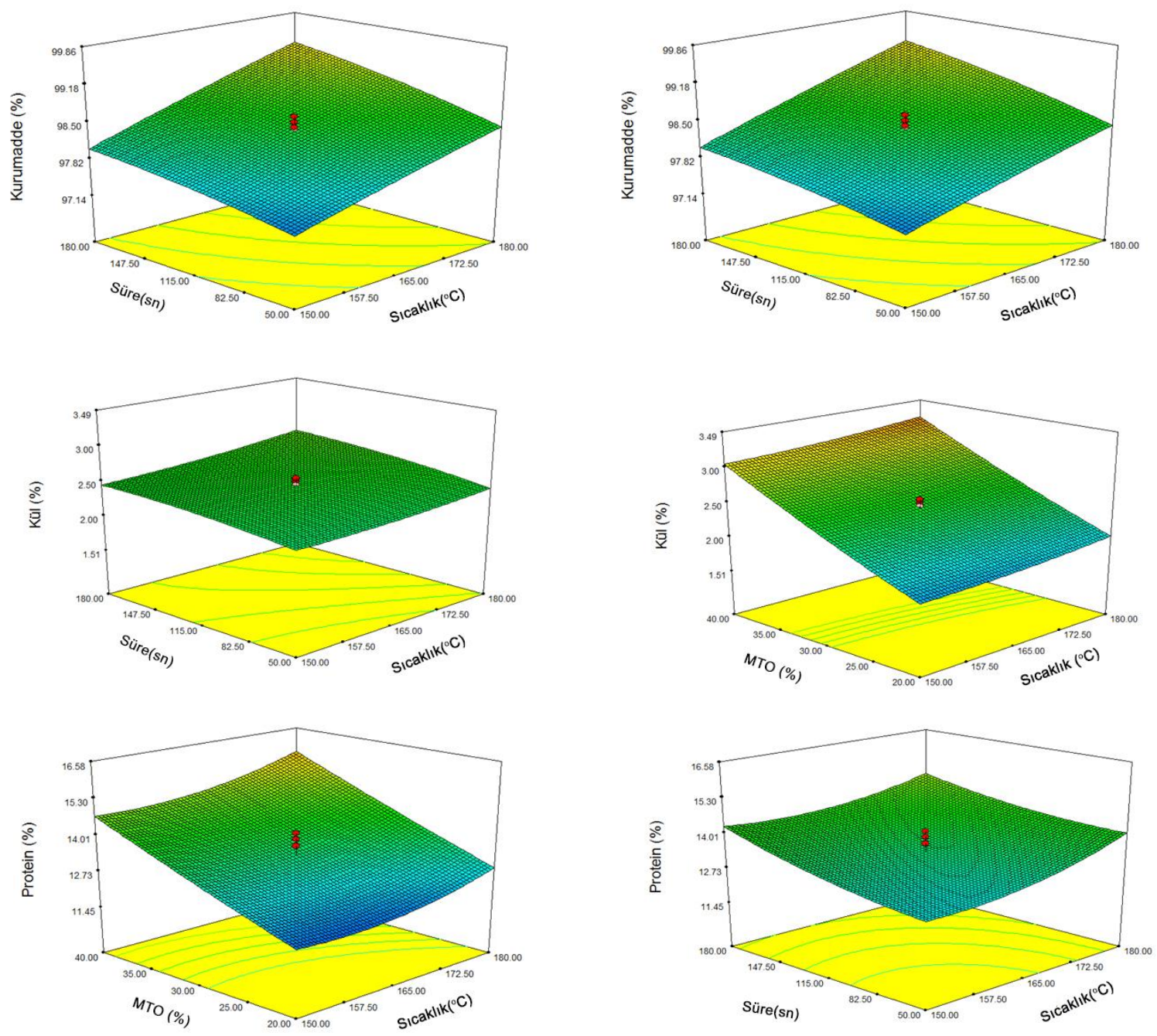

Şekil 2. Kızartılmış cips örneklerine ait kuru madde, kül ve protein miktarı üç boyutlu gösterimleri

Figure 2. Three-dimensional representation of dry matter, ash and protein content for fried chips samples
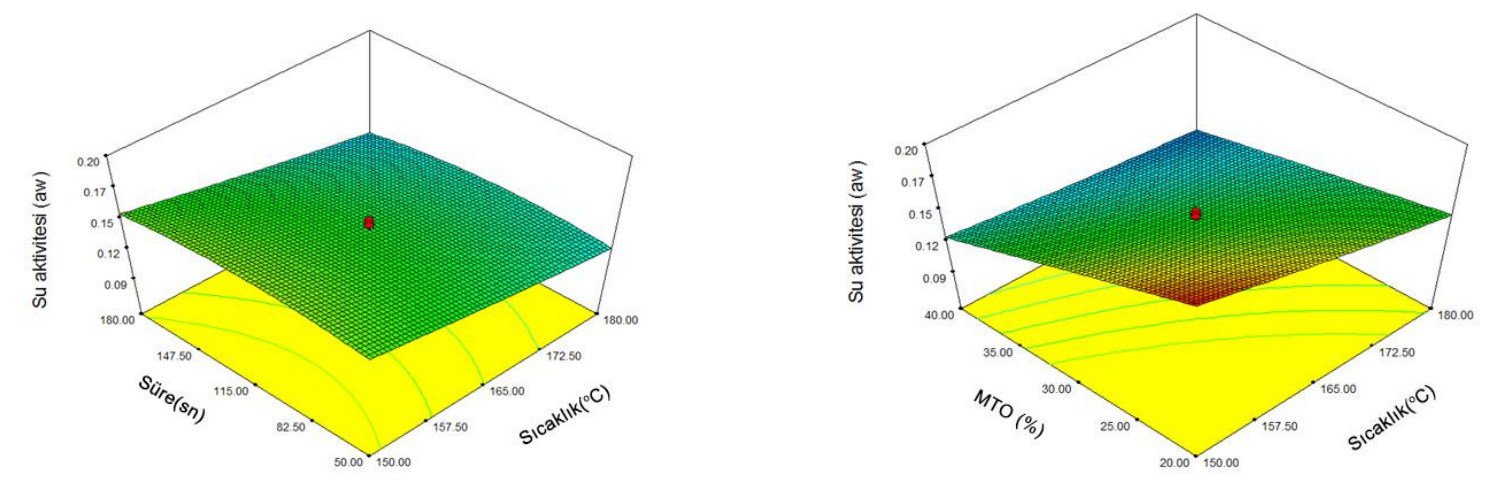

Şekil 3. Kızartılmış cips örneklerinin $a_{w}$ değerlerinin üç boyutlu gösterimleri

Figure 3. Three-dimensional representation of $a_{w}$ for fried chips samples 

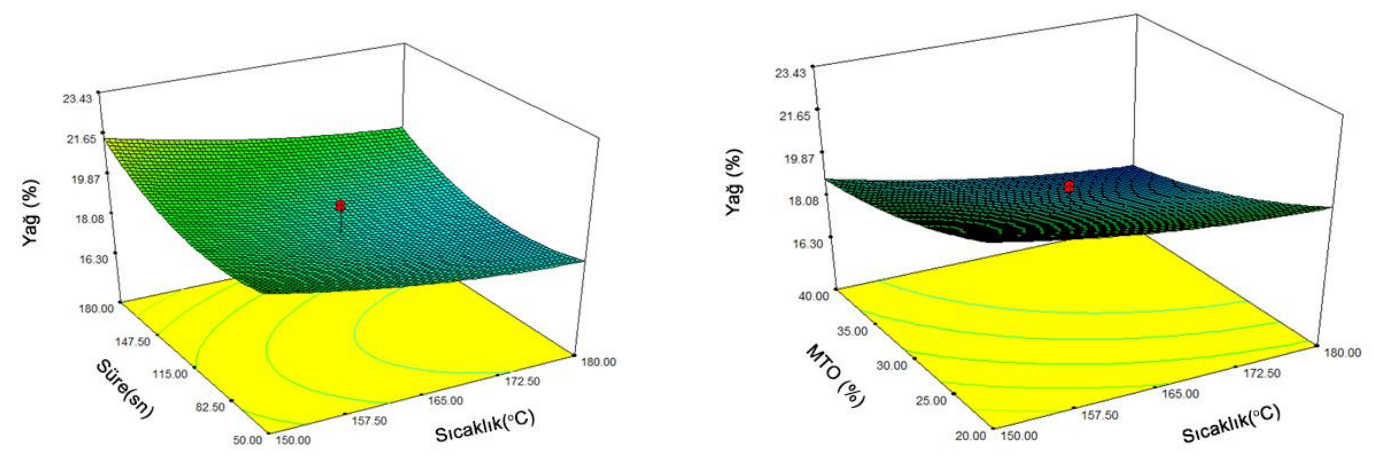

Şekil 4. Kızartılmış cips örneklerinin \% yağ miktarlarının üç boyutlu gösterimleri

Figure 4 Three-dimensional representation of \% fat amount for fried chips samples

\section{Duyusal Analiz}

Genel beğeni için RSM'de regresyon analizleri yapılmış olup, uygun modele ait 2 . dereceden (kuadratik) denklem aşağıda verilmiştir.

$Y=-25.59+0.38 X_{1}+0.04 X_{2}-0.31 X_{3}-3.14 E-$

$004 X_{1} X_{2}+1.71 E-004 X_{1} X_{3}+4.14 E-004 X_{2} X_{3}-$

$1.11 E-003 X_{1}^{2}+2.23 E-005 X_{2}^{2}-1.99 E-003 X_{3}^{2}$
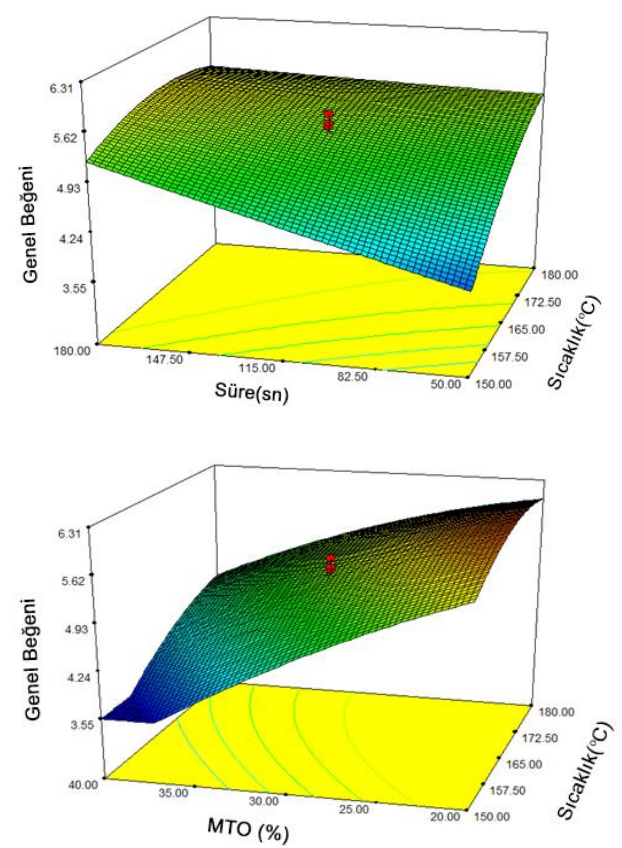

Şekil 5. Kızartılmış cips örneklerinin duyusal analiz değerlendirmesine ait üç boyutlu gösterimleri

Figure 5. Three-dimensional representation of sensory analysis evaluation for fried chips samples
Üç boyutlu gösterimlerden de anlaşılacağı üzere sıcaklık ve sürenin artması genel beğeniyi arttırırken, MTO'nun artması genel beğeniyi azaltmıştır $(p<0.05)$ (Şekil 5.).

\section{Optimizasyon}

Cipslerin fizikokimyasal ve duyusal değerlendirmesinden Desing Expert (Versiyon:7.0, StatEase, ABD) yazılımı kullanılarak kızartılmış cips için optimizasyonun kriterleri, bağımsız değişkenlerden kızartma sıcaklığı ve süresi deneme noktalarındaki değerler aralığında, MTO maksimum amaçla girilmiştir. Bağımlı değişkenlerden protein, genel beğeni maksimum amaçla, yağ ve su aktivitesi minimum amaçla, kuru madde ve kül değerleri ise tüm deneme dizaynları sonuçları için bulunan değerler aralığında olarak belirlenmiştir. Optimizasyon sonucunda $180{ }^{\circ} \mathrm{C}, 154.77$ sn kızartılan \%40 MTO katkılı cips örnekleri 0.841 arzu edilirlikte optimum norm olarak belirlenmiştir. RSM de elde edilen modelin güvenilirliğinin tespiti için, optimum noktada elde edilen model verileri deneysel veriler ile karşılaştırılmıştır. Model verileri; kurumadde, kül, protein, aw, yağ ve genel beğeni için sırası ile \%99.86, \%3.28, \%16.10, 0.10, \%17.61 ve 4.72 olarak belirlenmiştir. Optimum noktada elde edilen deneysel veriler ise; \%99.10, \%3.25, \%15.10, 0.10, \%19.02 ve 5.39 olarak belirlenmiştir. Sayısal 
verilere bakıldığında model veriler ile deneysel verilerin son derece yakın olduğu görülmektedir. Optimum noktada kabul edilebilirliğin 0.841 olması ve model veriler ile deneysel verilerin yakın sonuçlar vermesi seçtiğimiz modelin uyumluluğunu ve optimizasyon işleminin güvenilirliğinin yüksek olduğunu göstermektedir.

\section{Sonuçlar}

Çalışma kapsamında elde edilen sonuçlar mantar tozu katkılı cips örneklerinin, fizikokimyasal ve duyusal özellikleri açısından kabul edilebilir bir ürün olduğunu göstermektedir. Son yıllarda hastalıkların çoğalması ve bu hastalıkların yediklerimiz ile ilişkilendirilmesi, insanların sağlık konusunda gıdalarına daha fazla önem vermelerine neden olmuştur. Bilinçli tüketiciler hastalıktan önce sağlık önlemlerinin alınmasında kimyasal içerikli takviyeler yerine, doğal ürünlere yönelmeleri ile birlikte, zenginleştirilmiş gıda ürünlerine ilgi göstermektedir. Özellikle çağımızda çeşitli sosyokültürel etmenler insanların atıştırmalık ürünlere olan ilgisinin artmasına neden olmuştur. Zaten hali hazırda tüketim potansiyeli olan bu sektördeki ürünlerin doğal besin bileşenleri ile zenginleştirmenin üretici ve tüketiciler için olumlu sonuçlar doğuracağı düşünülmektedir. Ülkemizde zenginleştirilmiş atıştırmalık ürün sektöründe açık olduğu düşünülmekte olup bu konuda yapılacak bilimsel ve endüstriyel çalışmalara ihtiyaç duyulmaktadır.

\section{Ekler}

Bu araştırma makalesi HÜBAK 14044 nolu proje kapsamında desteklenmiştir. Değerli destekleri için HÜBAK birimine teşekkür ederiz. Ayrıca pleurotus ostreatus miselini temin eden Sylvan Tarım Ürünleri San ve Tic. Ltd. Şti.'ye teşekkür ederiz.

\section{Kaynaklar}

Afrin, S., Rakib, M. A., Kim, B. H., Kim, J. O., Ha, Y. L., 2016. Eritadenine from Edible Mushrooms Inhibits Activity of Angiotensin Converting Enzyme in Vitro. Journal of agricultural and food chemistry, 64(11): 2263-2268.

Aguilera, J. M., Arıas, E. P., 1992. CYTED-D AHI: An Ibero American Project on Intermediate Moisture Foods and Combined Methods Technology. International Foods Rescarch, 25: 159-165.

AOCS., 1999. Recommended Method of Analysis, AOCS, USA.

AOAC., 2000. Official methods of analysis (17th ed.). Arlington, VA: Association of Official Analytical Chemists, Inc.

Bobek, P., Ginler, E., Jurčovičová, M., Kuniak, L., 1991. Cholesterol-lowering Effect of The Mushroom Pleurotus ostreatus in Hereditary Hypercholesterolemia Rats. Annals of Nutrition and Metabolism, 35(4): 191-195.

Cankurtaran, M., 2008. Kızartılmış Buğday Cipsi Üretimi ve Elde Edilen Buğday Cipslerinin Kalite Özelliklerinin Belirlenmesi. Erciyes Üniversitesi, Fen Bilimleri Enstitüsü, Yüksek Lisans Tezi, Kayseri, $74 \mathrm{~s}$.

Cheskin, L. J., Davis, L. M., Lipsky, L. M., Mitola, A. H., Lycan, T., Mitchell, V., Mickle, B., Adkins, E., 2008. Lack of Energy Compensation Over 4 Days When White Button Mushrooms are Substituted for Beef. Appetite, 51(1): 50-57.

Doğan, N., 2015. Pleurotus ostreatus'tan Mantar Tozu Üretiminde Kurutma İşleminin Yanıt Yüzey Yöntemi Kullanılarak Optimizasyonu. Pamukkale Üniversitesi Mühendislik Bilimleri Dergisi, 21(9): 433437, 2015.

Doğan, N., 2016. İstiridye Mantarından (Pleurotus ostreatus) Mantar Tozu ve Cips Üretiminin Optimizasyonu. Harran Üniversitesi Fen Bilimleri Enstitüsü. Doktara Tezi, Ankara, 300s. (Yayınlanmamış).

Erbay, B., E. Küçüköner, 2008. Mantarın Besin Değeri ve Tüketim Şekilleri. Türkiye 8 . Yemeklik Mantar Kongresi Bildirisi, , 15-17 Ekim 2008, 181s. Kocaeli. 
Iwe, M. O., 2000. Effects of Extrusion Cooking on Some Functional Properties of Soy-Sweat potato Mixtures - A Response Surface Analysis. Plant Foods for Human Nutrition, 169-184.

Konopacka, D., Plocharski, W., Beveridge, T., 2002. Water Sorption and Crispness of Fat-Free Apple Chips. Journal of Food Sclence, 67: 87-92.

Martınez-Flores, H. E., Cruz, M. C., Larıos, S. A., Jimenez, G. E., Figueroa, J. D. C., 2005. Sensorial and Biological Evaluation of an Extruded Product Made From Corn Supplemented with Soybean and Safflower Pastes. International Journal of Food Science and Technology, 40: 517-524.

Mellema, M., 2003. Mechanism and Reduction of Fat Uptake in Deep-Fat Fried Foods, Trends in Food Sci. Technol., 14: 364-373.

Mulsaney, S. J., Hsieh, F. H., 1988. Process Control for Extrusion Processing, Cereal Food World, 33, 971.

Myers, R. H., Montgomery, D. C., 2002. Response Surface Methodology. Process and Product Optimization Using Design Experiments., A Wiley Inter-Science Publication, $792 \mathrm{p}$.

Öztürk, A., Çopur, Ö. U., 2008. Mantar Bileşenlerinin Teröpatik Etkileri. Atatürk Bahçe Kültürleri Merkez Araştırma. Bahçe Dergisi 37 (2): 11-17.Yalova.

Pesti, G., 2014. Mushrooms Cultivation, Antioxidant Properties and Health Benefits: Nova Publishers.

Poddar, K. H., Ames, M., Hsin-Jen, C., Feeney, M. J., Wang, Y., Cheskin, L. J., 2013. Positive Effect of Mushrooms Substituted for Meat on Body Weight, Body Composition, and Health Parameters. A 1-Year Randomized Clinical Trial. Appetite, 71: 379-387.

Poppe, J., 2000. Use of Agricultural Waste Materials in the Cultivation of Mushrooms. Proceedings of The 15 th International Congress on The Science and Cultivation of Edible Fungi, 3-23 pp. Netherlands.

Ragunathan, R., Swamınathan, K., 2003. Nutritional Status of Pleurotus spp. Grown on Various Agro-Wastes. Food Chemistry, 80: 371-375.

Sarangı, I., Ghosh, D., Bhutıa, S.K., Mallıck, S.K., Maıtı, T.K., 2006. Anti-tumor and Immunomodulating Effects of Pleurotus ostreatus Mycelia- Derived Proteoglycans.
International Immunopharmacology, 6: 1287-1297.

Schneider, I., Kressel, G., Meyer, A., Krings, U., Berger, R. G., Hahn, A., 2011. Lipid Lowering Effects of Oyster Mushroom (Pleurotus ostreatus) in Humans. Journal of Functional Foods, 3(1): 17-24.

Yüksel, F., 2014. Bayat Ekmeğin Kızartılmış Buğday ve Mısır Cipsinde Kullanımı. Erciyes Üniversitesi, Fen Bilimleri Enstitüsü, Gıda Mühendisliği, Doktora tezi, $173 s$. 